Jurnal Perikanan Pantura (JPP) Volume 1, Nomor 1, Maret 2018

\title{
PENGARUH PENAMBAHAN SERBUK DAUN TANAMAN KAYU MANIS (Cinnamomum burmannii) PADA PAKAN TERHADAP PROFIL DARAH (KADAR HEMATOKRIT, KADAR HEMOGLOBIN, TOTAL LEUKOSIT DAN TOTAL ERITROSIT) IKAN NILA (Oreochromis niloticus) YANG DIINFEKSI Streptococcus agalactiae
}

\author{
Sri Lestari ${ }^{1}$, Firma Fika Rahmawati ${ }^{2}$ dan Rahmad Jumadi ${ }^{2}$ \\ ${ }^{1}$ Mahasiswa prodi Budidaya Perikanan, Fakultas Pertanian, Universitas Muhammadiyah Gresik \\ ${ }^{2}$ Dosen Prodi Budidaya Perikanan, Fakultas Pertanian, Universitas Muhammadiyah Gresik \\ Email : tariko.2011@gmail.com, Phone: +628113347923
}

\begin{abstract}
Bacterial disease like Streptococcosis which is caused by Streptoccoccusagalactiae becomes the most important problem that often arise in the aquaculture business. The disease can be $100 \%$ cause of death. One of the prevention efforts is using phytopharmaca in cinnamon leaf (Cinnamomunburmanni). This traditional herb is eco-friendly, safe for consumers and it does not have any residue. Chemical compounds contained in cinnamon leaves have function as antioxidants, to increase metabolism, growth and non-specific immune response in fish. This study is to determine the effect and find the best dose of the addition of cinnamon leaf powder in food given to Tilapia that infected by Streptococcus agalactaiae. The tested dose is 0\%, 0.25\%, $0.5 \%, 1 \%$. Observed parameters were blood profile (hematocrit level, hemoglobin level, total erythrocytes and total leukocytes) and water quality. The results were analyzed by ANOVA using RAL with 95\% credibility level. The results obtained in the study by adding cinnamon leaf powder to the given food to tilapia that was infected by Streptococcus agalactiae affect the blood profile (hematocrit level, hemoglobin level, total erythrocytes and total leukocytes). A dose of $0.25 \%$ is the best dose for hematocrit level, hemogobline level and erythrocytes total. While the dose of $1 \%$ is the best dose for the total value of leukocytes. Doses of $0.25 \%$ and $1 \%$ can be applied to tilapia culture to prevent Streptococcosis disease caused by Streptococcus agalactiae bacteria.
\end{abstract}

Keywords : Tilapia, Cinnamon, Streptococcosis, Streptococcus agalactiae, Hematocrit, Hemoglobin, Erythrocytes, Leukocytes.

\section{PENDAHULUAN \\ Latar Belakang}

Penyakit bacterial merupakan salah satu masalah penting yang kerap timbul dalam usaha budidaya ikan air tawar.Salah satu penyakit bacterial yang akhir-akhir ini banyak menyerang ikan nila adalah streptococcosis yang disebabkan oleh bakteri Sreptococcus agalactiae.

Salah satu upaya yang berpeluang untuk diterapkan dalam pencegahan adalah penggunaan bahan fitofarmaka. Salah satu bahan fitofarmaka yang dapat dimanfaatkan adalah tumbuhan kayu manis (Cinnamomum burmannii). Tumbuhan kayu manis merupakan tanaman herbal yang mempunyai senyawa polipenol dan sinamaldehid yang berfungsi sebagai antioksidan dan dapat meningkatkan metabolisme glukosa darah dan asam lemak (Gruenwald et al, 2010). Menururt Jayaprakasha dan Rao (2011), menyatakan bahwa 
Jurnal Perikanan Pantura (JPP) Volume 1, Nomor 1, Maret 2018

kandungan sinamaldehid juga dapat meningkatkan metabolisme lemak dan berfungsi sebagai antioksidan.

\section{TINJAUAN PUSTAKA}

Ikan Nila (Oreochromis niloticus)

Ikan nila berasal dari Afrika bagian Timur. Ikan nila memiliki bentuk tubuh yang pipih ke arah vertikal (compress). Posisi mulut ikan nila terletak di ujung hidung (terminal) dan dapat disembulkan (Suyanto, 2003). Klasifikasi ikan nila (Oreochromis niloticus), menurut Saanin (1984), dalam Setiawan, (2012) adalah sebagai berikut :

$\begin{array}{ll}\text { Filum } & \text { : Chordata } \\ \text { Subfilum } & \text { : Vertebrata } \\ \text { Kelas } & \text { : Osteichtyes } \\ \text { Subkelas } & \text { : Acanthopterygii } \\ \text { Ordo } & \text { : Percomorphi } \\ \text { Subordo } & \text { : Percoidea } \\ \text { Famili } & \text { : Cichlidae } \\ \text { Genus } & \text { :Oreochromis } \\ \text { Spesies } & \text { : Oreochromis niloticus }\end{array}$

Daun Kayu Manis (Cinnamomun burmanii)

Kingdom : Plantae

Super Devisi: Spermatophyta

Divisi : Magnoliophyta

Class : Magnoliopsida

Ordo : Laurales

Famili : Lauraceae

Genus : Cinnamomum

Spesies :Cinnamomum burmanii

(Rismundar dan Paimin, 2001)

Kayu manis (Cinnamomum burmanni Nees ex B1.) merupakan rempah-rempah dalam bentuk kulit kayu yang biasa dimanfaatkan masyarakat Indonesia dalam kehidupan seharihari. Di dalam kayu manis (Cinnamomum burmanni Nees ex Bl.) terdapat kandungan senyawa kimia berupa fenol, terpenoid dan saponin yang merupakan sumber antioksidan (Selvi et.al, 2003:455). Kulit kayu manis memiliki zat aktif seperti flavanoid, saponin, tanin dan alkanoid (Azima et al. 2004). Menurut Kumar et al. (2005), senyawa-senyawa kimia dari tumbuhan dapat meningkatkan aktivitas sistem imun seperti senyawa flavonoid, fenolik, alkaloid dan terpenoid.

\section{Bakteri Streptococcus sp.}

Kingdom : Bacteria

Filum : Firmicutes

Kelas : Bacilli

Ordo : Lactobacillales

Family : Streptococcaceae

Genus :Streptococcus

Spesies :Streptococcus sp. 
Jurnal Perikanan Pantura (JPP) Volume 1, Nomor 1, Maret 2018

Streptococcus adalah sel sferis, coccus tunggal berbentuk batang atau ovoid dan tersusun seperti rantai. Coccus membelah pada bidang yang tegak lurus sumbu panjang rantai. Panjang rantai bervariasi dipengaruhi oleh factor lingkungan. Streptococcus merupakan bakteri gram positif, namun pada biakan yang lama dan bakteri yang mati streptococcus kehilangan gram positifnya dan terlihat seperti gram negatif. Hal ini dapat terjadi setelah inkubasi semalaman (Jawetz dkk, 2007).

\section{Sistem Hematologi Ikan}

Indikator parameter nilai hematologi yang memperlihatkan perubahan pada darah, meliputi: hemoglobin, hematokrit, trombosit, jumlah sel darah merah dan jumlah sel darah putih. Sel darah merah, sel darah putih dan platelet/thrombosit merupakan bagian dari elemen darah, sedangkan berbagai faktor koagulasi/zat pembekuan serta immunoglobulin adalah unsur penting dari protein plasma total. Fungsi utama sel darah merah ialah mengikat haemoglobin untuk trasnspor oksigen, sedangkan sel darah putih peran utamanya ialah dalam pertahanan tubuh terhadap infeksi microbial.

\section{Imunologi Ikan}

Sistem pertahanan tubuh terbagi atas pertahanan non spesifik dan pertahanan spesifik (Baratawidjaya, 2006). Pertahanan tubuh non spesifik merupakan pertahanan tubuh terdepan dalam menghadapi serangan berbagai mikroorganisme, yang dapat memberikan respon langsung terhadap antigen. Pertahanan non spesifik meliputi pertahanan fisik dan kimiawi seperti epitel dan substansi pada permukaan tubuh. Mekanisme pertahanan non spesifik pada tubuh adalah mucus, kulit, insang dan sel gastrointestinal (Nurcahyo, 2001).

\section{METODE PENELITIAN}

\section{Tempat dan Waktu}

Penelitian ini dilaksanakan pada bulan Agustus - September 2017 di Laboratorium Mikrobiologi dan Laboratorium Basah Program Studi Budidaya Perikanan Universitas Muhammadiyah Gresik.

\section{Rancangan Percobaan}

Rancangan percobaan yang digunakan Rancangan Acak Lengkap (RAL) dengan 4 perlakuan yaitu $0,25 \%, 0,5 \%$ dan $1 \%$ dan 3 ulangan serta control.

\section{Parameter penelitian}

Parameter utama yang diamati meliputi:

1. Kadar hematokrit

Kadar hematokrit diperiksa menurut Goldenfarb, et al. (1971) :

$$
\mathrm{He}=\frac{a}{b} \times 100 \%
$$

2. Kadar hemgoblin

$$
\text { Kadar hemoglobin diukur menurut metode sahli (Collier, 1944) }
$$

3. Total eritrosit

Jumlah eritrosit dihitung berdasarkan metode Oti \& Avoaja (2005)

jumlah eritrosit $=\left(\frac{A}{N}\right) \times\left(\frac{1}{V}\right) \times f p$

\footnotetext{
Keterangan:

$\mathrm{A}=$ Jumlah sel eritrosi terhitung

$\mathrm{N}=$ Jumlah kotak hemositometer yang diamati

$\mathrm{V}=$ Volume kotak hemositometer yang diamati

$\mathrm{Fp}=$ Faktor pengenceran
} 
Jurnal Perikanan Pantura (JPP) Volume 1, Nomor 1, Maret 2018

4. Total leukosit

Total leukosit dihitung dengan metode Oti \& Avoaja (2005).

Jumlah leukosit $=\left(\frac{A}{N}\right) \times\left(\frac{1}{V}\right) \times f p$

Keterangan:

A = Jumlah sel leukosit terhitung

$\mathrm{N}=$ Jumlah kotak hemositometer yang diamati

$\mathrm{V}=$ Volume kotak hemositometer yang diamati

$\mathrm{Fp}=$ Faktor pengenceran

Parameter pendukung yang diamati adalah kualitas air yang meliputi: suhu, $\mathrm{pH}$, dan DO.

\section{HASIL DAN PEMBAHASAN Kadar Hematokrit}

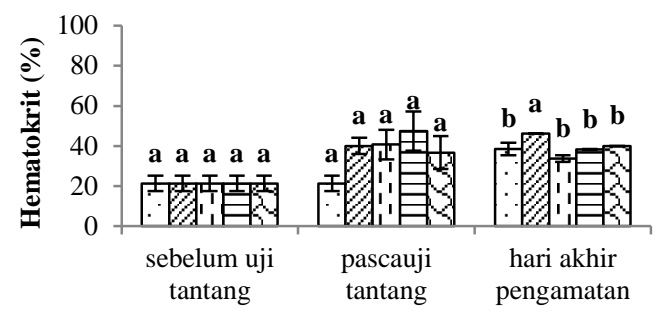

Gambar 1.Hasil pengamatan kadar hematokrit pada ikan nila dengan penambahan serbuk daun tanaman kayu manis dengan dosis berbeda ( $\square) \mathrm{K}-$ : kontrol negatif, ( $\square) \mathrm{K}+$ : Kontrol positif, (-)A: penambahan serbuk daun tanaman kayu manis dengan dosis $0.25 \%$, (国) B: penambahan serbuk daun tanaman kayu manis $0.5 \%$, (圈)C: penambahan serbuk daun tanaman kayu manis $1 \%$.

Berdasarkan hasil pengamatan kadar hematokrit pada ikan nila setelah infeksi Streptococcus agalactiae mengalami peningkatan pada semua perlakuan sampai hari terakhir. Peningkatan tertinggi terjadi pasca uji tantang yaitu pada perlakuan B sebesar $47,45 \% \pm 9,77 \%$ berbeda nyata $(\mathrm{p}<0.05)$ dengan kontrol. Hal ini mengindikasikan bahwa senyawa bioaktif dalam serbuk daun tanaman kayu manis memberikan efek kesehatan yang baik pada ikan. Pernyataan ini didukung oleh Talpur (2013) bahwa tanaman herbal dapat meningkatkan fungsi kekebalan tubuh dengan mempengaruhi sel-sel darah.

Menurut Tanbiyaskur (2011) bahwa indikator ikan terkena infeksi, rendahnya kandungan protein pakan dan defisiensi vitamin dapat dilihat dari pengamatan kadar hematokrit. Fergusan 1988 dalam Mudjiutami et al, (2007) melaporkan bahwa variasi nilai hematokrit tinggi karena sangat dipengaruhi oleh umur, jenis kelamin, waktu pemeriksaan, temperatur air, metode pengambilan sampel tipe dan lama anestesi. Pada hasil pengamatan masing-masing perlakuan dosis pakan dengan penambahan serbuk daun kayu manis selama pemeliharaan, kadar hematokrit ikan uji menunjukkan nilai yang normal yaitu masih dalam kisaran rataan. Hal ini menunjukkan bahwa pemberian serbuk daun tanaman kayu manis dalam pakan ikan nila memberikan efek kestabilan kadar hematokrit, baik setelah pemberian pakan serbuk daun tanaman kayu manis maupun setelah infeksi Streptococcus agalactiae. 
Jurnal Perikanan Pantura (JPP) Volume 1, Nomor 1, Maret 2018

Kadar Hemogoblin

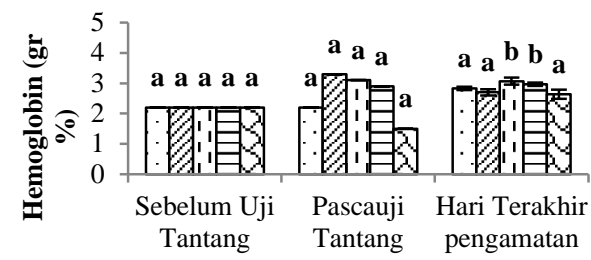

Gambar 2. Hasil pengamatan kadar hemogoblin pada ikan nila dengan penambahan serbuk daun tanaman kayu manis dengan dosis berbeda. ( $\square) \mathrm{K}-$ : kontrol negatif, ( $\square) \mathrm{K}+$ : Kontrol positif, (-)A: penambahan serbuk daun tanaman kayu manis dengan dosis $0.25 \%$, (国)B: penambahan serbuk daun tanaman kayu manis 0.5\%, (图)C: penambahan serbuk daun tanaman kayu manis $1 \%$.

Berdasarkan hasil pengamatan dapat dilihat bahwa setelah dilakukan infeksi Streptococcus agalalactiae kadar hemoglobin pada masing-masing perlakuan mengalami peningkatan. Kadar hemoglobin tertinggi yaitu terjadi pada hari terakhir pada perlakuan A sebesar 3.07\% \pm 0.12 (Lampiran 6) dan berbeda nyata $(\mathrm{p}<0.05$ ) dengan kontrol $(\mathrm{K}+)$ dan penurunan kadar hemoglobin terjadi pada perlakuan $\mathrm{C}$ pascauji tantang. Meskipun pada hari terakhir nilai kadar hemaglobin tertinggi kurang dari nilai kisaran normal, ikan masih bisa bertahan hidup.

Penurunan kadar hemoglobin diduga karena senyawa saponin yang terdapat pada serbuk daun tanaman kayu manis dapat melisis sel darah merah, sehingga nilai total eritrosit ikan nila menjadi turun. Eritrosit yang lisis mengalami kerusakan baik pada membran dan hemoglobinnya. Nilai hemoglobin yang rendah menyebabkan metabolisme menjadi terhambat dan energi yang dihasilkan menjadi sedikit, sehingga membuat ikan menjadi tampak lemah, nafsu makan berkurang serta terlihat didasar kolam dan berenang sangat lemah, hal ini berdampak pada pertumbuhan ikan yang rendah (Hardi et al, 2011).

\section{Total Eritrosit}

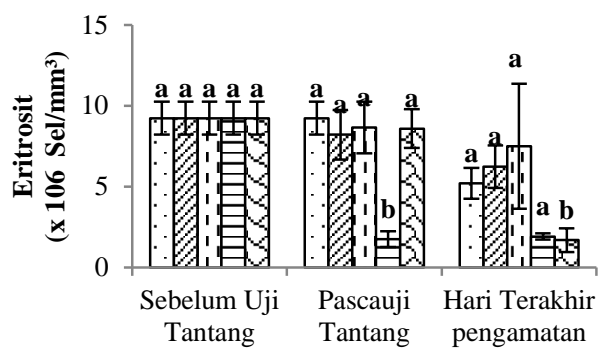

Gambar 3. Hasil pengamatan total eritrosit pada ikan nila dengan penambahan serbuk daun tanaman kayu manis dengan dosis berbeda $(\square) \mathrm{K}$-: kontrol negatif, ( $\square$ (W+: Kontrol positif, (-)A: penambahan serbuk daun tanaman kayu manis dengan dosis $0.25 \%$, (国)B: penambahan serbuk daun tanaman kayu manis $0.5 \%$, (图薏)C: penambahan serbuk daun tanaman kayu manis $1 \%$.

Berdasarkan hasil dari pengamatan diatas dijelaskan bahwa ikan yang telah di infeksi Streptococcus agalactiae nilai total eritrosit mengalami penurunan secara terus menerus. Nilai total eritosit tertinggi terjadi pasca uji tantang yaitu pada perlakuan A sebesar $8.66 \pm 1.60 \times 10^{6}$ $\mathrm{sel} / \mathrm{mm}^{3}$ (Lampiran 8) berbeda nyata $(\mathrm{p}<0.05)$ dengan kontrol $(\mathrm{K}+)$. Penurunan secara drastis 


\section{Jurnal Perikanan Pantura (JPP) Volume 1, Nomor 1, Maret 2018}

terjadi pada hari terakhir yaitu pada perlakuan $\mathrm{B}\left(1.92 \pm 0.20 \times 10^{6} \mathrm{sel} / \mathrm{mm}^{3}\right) \mathrm{dan} \mathrm{C}\left(1.70 \pm 0.74 \times 10^{6}\right.$ $\left.\mathrm{sel} / \mathrm{mm}^{3}\right)$ berbeda nyata $(\mathrm{p}<0.05)$ dengan kontrol $(\mathrm{K}+)$. Hal ini diduga karena terjadi fagositosis bakteri yang masuk. Proses tersebut membutuhkan oksigen sehingga terjadi penurunan eritrosit.

Menurut Fadhilah (2009), bakteri yang masuk kedalam tubuh, akan terjadi proses fagositosis dimana sel-sel fagosit akan mengenali dan mencerna partikel-partikel bakteri yang membutuhkan oksigen sehingga terjadi penurunan eritrosit. Rendahnya nilai total eritrosit dari hasil pengamatan masih dalam kisaran normal.Berkurangnya sel eritrosit disebabkan karena terjadi anemia pada ikan (Aryanto, 2011). Menurut Fujaya (2004) bahwa ada indikasi keterkaitan total eritrosit dengan kandungan hemoglobin dan hematokrit.

\section{Total Leukosit}

Pengamatan total leukosit selama 14 hari setelah infeksi Sreptococcus agalactiae (N14G). Pengaruh penambahan serbuk daun tanaman kayu manis terhadap total eritosit ikan nila setelah infeksi streptococcus agalactiae (N14G) disajikan pada gambar berikut:

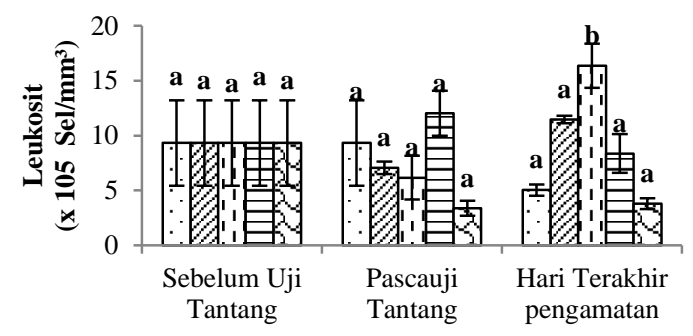

Gambar 4. Hasil pengamatan totalleukosit pada ikan nila dengan penambahan serbuk daun tanaman kayu manis dengan dosis berbeda (W)K-: kontrol negatif, (W)K+: Kontrol positif, (-)A: penambahan serbuk daun tanaman kayu manis dengan dosis $0.25 \%$, (国)B: penambahan serbuk daun tanaman kayu manis $0.5 \%$, (圈意)C: penambahan serbuk daun tanaman kayu manis $1 \%$.

Berdasarkan pada gambar diatas hasil pengamatan menunjukkan bahwa terjadi peningkatan nilai total leukosit pada hari terakhir. Nilai total leukosit tertinggi yaitu pada perlakuan A $(0.25 \%)$ sebesar $16.37 \pm 1.19 \times 10^{5} \mathrm{sel} / \mathrm{mm}^{3}$. Kisaran nilai total leukosit berada diatas nilai kisaran tidak normal. Kenaikan jumlah sel leukosit diduga karena adanya kenaikan pertahanan seluler akibat infeksi bakteri. Leukosit yang tinggi menandakan ikan dalam kondisi yang kurang sehat, dimana banyak ditemukan ikan yang berenang tidak normal, dan ditemukan banyak ikan yang mati.

nilai total leukosit yang meningkat disebabkan karena kandungan flavonoid dalam serbuk daun tanaman kayu manis yang mampu mengaktifkan sistem limfa pada ikan dalam meningkatkan produksi leukosit untuk melawan patogen yang masuk dengan cara melokalisasi dan mengeliminir patogen yang menyerang. Pernyataan ini didukung oleh Hardi et al, (2011) bahwa sel-sel tubuh leukosit tersebut bekerja untuk memfagosit bakteri agar tidak dapat berkembang dan menyebarkan virulensi dalam tubuh inang setelah uji tantang. Peningkatan jumlah leukosit terkait dengan kerja imun ikan dalam mereduksi serangan pathogen. Semakin meningkatnya serangan pathogen maka akan semakin meningkat pula produksi leukosit dalam darah. Pernyataan ini didukung oleh Martin et al, (2004) bahwa respon ikan terhadap stressor tergantung pada jenis stress yang dialami oleh ikan tersebut. Dimana peningkatan jumlah sel darah putih, penurunan hematokrit dan peningkatan neutrofil bergantung pada jenis stress yang 
Jurnal Perikanan Pantura (JPP) Volume 1, Nomor 1, Maret 2018

dialami ikan. Amlacher (1970) juga menyatakan bahwa darah akan mengalami perubahan yang serius khususnya apabila terkena penyakit infeksi.

\section{Kualitas Air}

Parameter kualitas air yang diamati dalam penelitian ini meliputi suhu, $\mathrm{pH}$, dan DO. Berdasarkan hasil pengamatan, parameter kualitas perairan media budidaya dalam kondisi normal dan optimal (Tabel 12.)

Tabel 1. Parameter Kualiatas Air selama 14 hari

\begin{tabular}{llll}
\hline \multirow{2}{*}{ Perlakuan } & \multicolumn{3}{l}{ Kisaran Kualitas Air } \\
\cline { 2 - 4 } & Suhu $\left({ }^{\circ} \mathbf{C}\right)$ & pH & DO(mg/l) \\
\hline K(Kontrol) & $26,9-31,97$ & $8,82-8,92$ & $5,37-6,37$ \\
A (Konsentrasi 0,25\%) & $26,43-29,1$ & $8,69-8,9$ & $4,8-6,33$ \\
B (Konsentrasi 0,5\%) & $26,83-29,73$ & $8,52-8,89$ & $4,77-6,37$ \\
C (Konsentrasi 1\%) & $26,53-30,77$ & $8,8-9,4$ & $4,9-5,97$ \\
\hline Kisaran (Sunarso, 2008) & $25-30^{\circ} \mathrm{C}$ & $6,5-8,5$ & $>3 \mathrm{mg} / \mathrm{l}$ \\
\hline
\end{tabular}

\section{KESIMPULAN}

Berdasarkan hasil dan pembahasan dapat disimpulkan bahwa penambahan serbuk daun tanaman kayu manis dengan dosis yang berbeda pada pakan berpengaruh terhadap profil gambaran darah. Dosis $0,25 \%$ adalah dosis terbaik untuk kadar hematokrit, kadar hemogoblin dan total eritrosit. Sedangkan dosis $1 \%$ merupakan dosis terbaik untuk nilai total leukosit.

SARAN

1. Dosis $0,25 \%$ dan $1 \%$ dapat diaplikasikan dalam pakan guna pencegahan penyakit Streptococcosis pada kegiatan budidaya ikan nila.

2. Perlu dilakukan penelitian lebih lanjut penggunaan serbuk daun tanaman kayu manis dengan frekuensi yang berbeda untuk efisiensi aplikasinya dalam pakan sebagai pencegahan penyakit Streptococcosis.

\section{UCAPAN TERIMAKASIH}

1. Ibu Ir. Endah Sri Redjeki, M.P., M.Phil selaku Dekan Fakultas Pertanian Universitas Muhammadiyah Gresik

2. Bapak Dr. Andi Rahmad Rahim, S.Pi., M.P selaku Ketua Program Studi Budidaya Perikana Universitas Muhammadiyah Gresik.

3. Bapak Ir. Rahmad Jumaidi, M.Kes dan Ibu Firma Fika Rahmawati S.Pi., M.Si selaku Dosen Pembimbing Skripsi Program Studi Budidaya Perikanan Universitas Muhammadiyah Gresik.

4. Semua pihak yang telah membantu dalam penyusunan Jurnal ini.

\section{DAFTAR PUSTAKA}

Amlacher E. 1970. Textbook of Fish Disease. DA Courey, RL Herman, Penerjemah New York: TFH Publ. Neptune. 302 pp.

Arie, V. 2007. Pembenihan dan Pembesaran Nila GIFT. Penebar Swadaya, Jakarta.

A.T Selvi, G.S. Joseph,, and G.K.,Jayaprakarsa. (2003). Inhibition Of Growth And Aflatoxin Production In Aspergillus Flavus By Garcinia Indica Extract And Its Antioxidant Activity.J. Food Microbiology 20. hal. 455

Azima, F. 2004. Aktivitas Antioksidan dan anti-agregasi platelet ekstrak cassiavera (Cinnamomum burmanni Nees ex Blume) serta potensinya dalam pencegahan 
Jurnal Perikanan Pantura (JPP) Volume 1, Nomor 1, Maret 2018

aterosklerosis pada kelinci[disertasi]. Bogor: Sekolah Pasca Sarjana, Institusi Pertanian Bogor.2006. Imunologi Dasar. Edisi Keenam. Balai Penerbitan Fakultas Kedokteran Universitas Indonesia. Jakarta. 572 hal.

E. E. Oti and D. A. Avoaja. 2005. Haematological Assessment of Freshwater Catfish Clarias garipinus (Burch) and "Heteroclarias" (Hybrid) Exposed to Sublethal Concentration of Zinc. College of Natural Resources and Environmental Management and Department of Biological Sciences, Michael Okpara University of Agriculture, Umudike-PMB 7267, Umuahia, Abia State, Nigeria. Pakistan J. Zool. Vol. 37(2),PP. 101-105.

Effendi H. 2003. Telaah Kualitas Bagi Pengolahan Sumber Daya dan Lingkungan Perairan. Yogyakarta. Kanisius

Fadhilah, D.N. 2009. Profil Darah Ikan Nila Merah (Oreochromis niloticus) Hibrid yang diinfeksi Bakteri Streptococcus agalactiae Dengan Kepadatan Berbeda. FPIK UNDIP. Semarang. Skripsi $84 \mathrm{hlm}$

Fujaya Y. 2004. Fisiologi Ikan. Dasar Pengembangan Teknologi Perikanan. Jakarta (ID). Rineka Cipta.

Gruenwald J, Freder J, Armbruster N. 2010. Cinnamon and Health. Critical Reviews In Food Science and Nutrition. 50(9):822-834.

Hardi EH. 2011. Kandidat Vaksin Potensial Streptococcus agalactiae untuk Pencegahan Penyakit Streptococcosis pada Ikan Nila (Oreochromis niloticus). [Disertasi].Bogor. Institut Pertanian Bogor.

Jawetz, E. dkk. 2007. Mikrobiologi Kedokteran. Jakarta: EGC.

Jayaprakasha GK dan Rao LJM. 2011. Chemistry, Biogenesis, and Biological Activities of Cinnamomun zeylanicum. Critical Reviews In Food Science and Nutrition. 51:547-562.

Mudjiutami E, Ciptoroso, Zainun Z, Sumajo, Rahmat. 2007. Pemanfaatan imuno-stimulan untuk pengendalian penyakit pada ikan mas. Jurnal Budidaya Air Tawar, 4(1): 1-9

Rismunandardan Paimin, F.B., 2001, Kayu Manis Budidaya dan Pengolahan,Penebar Swadaya, Jakarta

Setiawan.2012. Mengenal Berbagai Ikan dan Klasifikasinya. Info Seputar Ikan Kita, [online], (http://andre4088.blogspot.com/Morfologi-Ikan-Nila.html)

Suyanto, S.R., 2003. Nila.PenebarSwadaya. Jakarta. 105 halaman

Talpur AD dan Ikhwanuddin M. 2013. Azadiracha indica neem leaf dietary effect on the immunity response and disease resistance of Asian seabass, later calcarifer with Vibrio harveyi. Fish Shellfish immunol. 34: 254-26

Tanbiyaskur. 2011. Efektivitas Pemberian Probiotik, Prebiotik dan SinbiotikMelalui Pakan Untuk Pengendalian Infeksi Srteptococcus agalactiae pada ikan nila (Oreochromis nilaticus). [Tesis]. Program Pascasarjana, Institut Pertanian Bogor, Bogor. 